largely developed, as in the dog, cat, and rabbit, strongly bears out this view."

(6) The lower part of the temporo-sphenoidal lobe, close to the subiculum, is probably to be regarded as the centre of taste.

Evidence.-Electrical excitation of this region produces movements of the lips, tongue, and cheek-pouches, which "may be taken as reflex movements consequent on the excitation of gustatory sensation." And the abolition of taste coincides with (bilateral) destruction of this region.

(7) The pre-frontal region is probably related to the reflective and intellectual faculties.

(8) The occipital lobe is related to the visceral sensations, such as hunger and thirst. The evidence in favour of this opinion was regarded even by its author at the time as very inconclusive, and since the subject is entirely ignored in the later edition we need not further consider it.

$$
\text { E. A. SCḦ̈FER }
$$

(To be continued.)

\section{THE UNIVERSITY COLLEGES}

$\mathrm{T}^{\mathrm{H}}$ $\mathrm{HE}$ other day (March 3) the Times printed a letter from Prof. Jowett containing a powerful appeal to the State on behalf of the University Colleges which have recently been established in large towns by the exertions of private individuals. On Monday evening last, Mr. Mundella, having asked the Chancellor of the Exchequer whether his attention had been called to this letter, proceeded to inquire whether the Government "would introduce or facilitate the passing of a measure authorising local authorities to contribute towards the establishment and maintenance of schools and colleges adapted to the wants of their several localities, and would recommend to Parliament annual grants in aid of the same." That Mr. Goschen, so far as his personal sympathies are concerned, would have liked to give an affirmative answer to this question there can be no doubt; but, speaking as a member of the Government, he adopted a very discouraging tone. $\mathrm{He}$ was not in a position, he said, to recommend to Parliament annual grants in aid of local colleges. He admitted that it was an open question whether local authorities should not be empowered to aid such institutions, but the Government could not undertake to introduce or facilitate the passing of a measure dealing with the matter.

This decision is greatly to be regretted, and we must hope that the Government will soon be compelled by the pressure of public opinion to reconsider the subject. No one disputes that the University Colleges have done, and are doing, most valuable service to the communities in the midst of which they are placed. Until they were established, what is called a University education was accessible only to very well-off persons. The University Colleges have brought a high intellectual training within reach not only of the middle classes, but of working men and large numbers of eager and intelligent students have taken advantage of the opportunities provided for them. Even, therefore, if no material benefit were derived by the nation directly from the University Colleges, it would be the clear duty of the State to afford them the help they need. But from the point of view of industry and commerce, as well as from the purely intellectual point of view, it is hardly possible to overrate the importance of these colleges. That our traders are being driven by German and other competitors from important markets is, unfortunately, only too certain; and it is not less certain that they will never recover the ground they have lost until English industry in all its branches is carried on in accordance with strictly scientific methods. This is beginning to be pretty generally understood, and it will be strange if the country does not insist that justice shall be done to institutions in which a serious attempt is being made to impart the kind of knowledge without which it is impossible for manufacturers to adapt their work to the rigid conditions of the present age.

No doubt it would be very satisfactory if the University Colleges could be made self-supporting, but this they cannot be. If those of them which do not possess any considerable endowment receive no aid from the Government, they will soon be placed in a position of grave difficulty; and the question will have to be faced, whether it is worth while to maintain them at all unless they can be maintained in a state of high efficiency. After all, it is no very great sacrifice that the State is asked to make for their benefit. What is clained is simply that not less shall be done for the English colleges than is done for like institutions in Scotland, Ireland, and Wales.

An aspect of the question which does not always receive adequate attention was well brought out in Prof. Jowett's admirable letter. "Among other benefits," he wrote, "the influence which is exercised by these institutions on the society of a place is not to be forgotten. The residence in a large manufacturing town of a number of highly educated persons, having a variety of literary and scientific interests, is a social element of great value. They raise the tone of conversation; they create ideas and aspirations which would not ordinarily have arisen in a mercantile community. They break in on the dull monotony of wealth. The posts which they occupy, though poorly paid, afford leisure for study and opportunities for research. Among the holders of them are to be found some of the most promising young men of the country. Many of them are known by their writings, and a large proportion of the papers published in English scientific periodicals is a record of the work done in University Colleges."

The Times, we are glad to say, cordially supports the cause advocated by the Master of Balliol. "The good," it says (March 3), "which the local colleges do is not exaggerated by Prof. Jowett. They form centres of instruction for all the young men and young women of a town who desire to improve themselves. They foster the love of study, and teach the art of making use of time. 'They may have even kindled in the minds of one or two the spark of genius.' To put the matter on a lower but not less practical level, they have done much, by means of their technical schools, to provide that very instruction of which, as everyone admits, our artisans are so much in need to enable them to carry on the struggle for existence against foreign rivals. Nor does the Master overstate the advantages which the town indirectly derives from the presence of these colleges, whose teacbing staff do much to raise the tone of social life throughout the district. It is a sound argument of the defenders of the Church Establishment that it is a great gain to English society to have at least one educated gentleman settled in every parish. The argument may be extended in favour of the University Colleges, and we may say that in a large town, where the pursuit of wealth through commerce is the characteristic of the whole society, it is a great advantage to have four or five men of high intellectual training, whose aims are different, whose standard is different, and who represent science and literature sometimes with great distinction. It would on many grounds be matter for extreme regret if the excellent institutions which foster such men should disappear. Yet there is too much reason to fear that such will be the fate of most of them, unless help more permanent and certain than any that can be derived from voluntary sources is at once forthcoming. Neither Leeds, New castle, Sheffield, Nottingham, nor Bristol is in a satisfactory financial condition. The fees cannot pay even the very modest stipends of the professors, and the annual subscriptions are showing a lamentable tendency to diminish. It seems as though there was nothing for it but an appeal to the Exchequer, sorely tried as it now 
is, and growing as is the need for economy. . . . The University Colleges during fifteen years have proved their value; and also, like every other educational institution, they have proved that they cannot live without external help. The only help that is likely to be permanent and that will enable them to feel secure is help from the State; and, in a moderate degree, it will be worth the State's while to give it."

The opinions of men of science on the subject were expressed in a letter from Sir Henry Roscoe, which appeared in the Times on Saturday last. "It is unnecessary now," he wrote, "to enlarge on the important national work in which these colleges are engaged. That the higher scientific and technical training which these colleges are now giving to the best of their power is a necessity, indorsed as this opinion has been by two Royal Commissions, is now, I am glad to think, generally admitted. It is, however, perfectly clear that if these colleges are to do the work which the country demands they must receive pecuniary assistance. They cannot from their very nature be made self-supporting. Their object is to afford a thorough but also a cheap education, and the localities have in almost all cases now practically exhausted the power of raising funds from private sources. How, then, are the necessary means to be found? 'They must come either from Imperial or from municipal sources. As the Master has pointed out, the remedy must be a speedy one. We cannot afford to wait until public opinion has reached the point at which ratepayers generally are convinced that it is to their advantage to support such colleges. The only alternative, therefore, is that the nation as a whole shall, through the Government, acknowledge its obligation to supply the necessary funds, the amount required being comparatively small and not one likely largely to increase. It is satisfactory to know that the whole subject of the furtherance of scientific and technical education in the country is at the present moment under the serious consideration of Members of Parliament of all political parties, and I have good reason to hope that our efforts to bring this question, vital as it is to the industrial and commercial supremacy of the country, to a satisfactory issue may, even this Session, be crowned by some measure of success. Among the several important matters engaging our attention, I need scarcely say that this particular one, affecting as it does the higher technical education of those who are hereafter to takc positions as leaders in our commerce and industries, is by no means the least important."

We trust that the new impetus now given to this question may lead to beneficial results. It is to be hoped, however, that we shall hear less of the word "technical" in connection with these colleges, for if they are technical only, we may be better without them.

THE EARTHQUAKE IN SWITZERLAND

DROF. FOREL, the meteorologist, of Morges, on the Lake of Geneva, has just issued a report on the earthquake of February 23. He classifies the shocks under three heads-namely, preparatory shocks, strong shocks, and consecutive shocks. It is difficult, in the absence of trustworthy data, to indicate the precise locality of the firstnamed, but Switzerland was undoubtedly the region of the second ; but it was to the third-that is, the consecutive shocks - that all the mischief was due. The professor traces the course of the phenomenon in Switzerland over a radius of at least four hundred square miles. Its force was greater in the southern parts of the country than in the north, though the shocks were felt throughout Geneva, Berne, Neuchâtel, Fribourg, Vaud, Valais, and Tessin; and observations go to prove that these shocks travelled almost due north and south, although the direction of the oscillations does not coincide with this course. The oscillations in Switzerland were characterised by their number and repetitions. In some localities they were longitudinal; that is, running parallel to the meridian; in others they were transverse, running or flowing from east to west. The vertical movements were marked by their feebleness where indicated, but in the greater part of the territory affected vertical oscillations were entirely absent. One of the peculiarities of the oscillations generally was the length of duration, which is set down as varying from Io to 30 seconds. But the collected reports prove that the mean of these figures more nearly represents the prevailing duration. The intensity of the shocks was greater in the central and southern areas of the disturbance, and it would seem as if the shocks only just failed to attain the necessary strength which would have produced disastrous effects. As it was, church bells were rung, in some places violently; windows were rattled, doors thrown open, ceilings slightly cracked, and morsels of plaster were brought down, and here and there stacks of wood were thrown over. One of the most striking features of the phenomenon was the extraordinarily large number of clocks that were instantly stopped, and this fact has afforded the best possible means of determining with something like perfect accuracy the time of the shocks, which varies from three to four minutes past six in the morning, Berne time. The large astronomical clock of the Observatory at Basle stopped exactly at 6h. $4 \mathrm{~m} .7 \mathrm{~s}$. This, taken as representing Berne time, corresponds with $5 \mathrm{~h} .43 \mathrm{~m}$. $35 \mathrm{~s}$. of Paris, $5 \mathrm{~h} .55 \mathrm{~m}$. $43 \mathrm{~s}$. of Marseilles, 6h. $3 \mathrm{~m}$. 2s. of Nice, and $6 \mathrm{~h} .24 \mathrm{~m}$. 3s. of Rome.

The consecutive shocks, which were responsible for all the loss of life and damage to property, were centralised in the region of the Rivicra. The greatest damage was done by the two first shocks, which occurred with an interval of fifteen minutes between them. The reports from the Swiss observatories also show that a series of feebler shocks were experienced in Switzerland later on in the same day, and also on several succeeding days.

\section{NOTES}

Several schools of science and art in the colonies and dependencies of the United Kingdom have expressed a wish to be allied with the Department of Science and Art and to have the advantage of its examinations. It has therefore been decided that upon the application of the Colonial Government or Educational Department, or other public authority of the colony, the Department of Science and Art will arrange for the examination of their schools, on the results of which examination certificates and returns of awards will be issued. The entire cost of the examination of the papers and works, and of their carriage, clearing in London, and conveyance to and from South Kensington, will, of course, bave to be defrayed by the local authority concerned. The personal examinations, the subjects of which are stated in the Science and Art Directory, must be held in the colonics and dependencies upon the earliest date possible after the receipt of the examination papers, and these examinations must be conducted by qualified and responsible persons not immediately interested in the results of the examinations, who should on the conclusion of each examination furnish a certificate that the examination has been fairly conducted. The examination of works is held at South Kensington, and works to be examined must be forwarded to reach South Kensington not later than the end of A pril in each year. The Department will send upon application copies of lists of examples and prizes, and will, as far as possible, advise the local authorities in reference to the conduct of science and art schools or classes. The Department will also present specimen examination papers or works-when there are such in stock disposable-with the view of indicating the style of drawings 